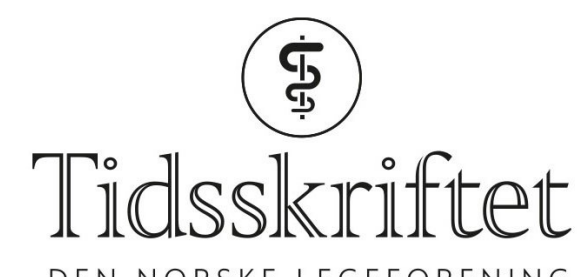

DEN NORSKE LEGEFORENING

\title{
Gjør dagen lysere!
}

TIDLIGERE I TIDSSKRIFTET

\section{SYNNE LOFSTAD}

E-post: synne.lofstad@hotmail.com Redaksjonssjef i Æsculap

Ikke helt sjelden står det «trøtt og sliten» bak pasientens navn i timeboka. Hvis det ikke er en åpenbar mangel på vitamin D eller jern, sendes ofte pasienten og fastlegen ut på en tålmodighetsprøve av en leteaksjon. Kanskje det var lettere i 1958, da hadde man i hvert fall én medisin å foreslå? Ritalin ble opprinnelig brukt til å behandle narkolepsi, depresjon og hukommelsesproblemer hos eldre. Det var ikke før i 1960 at preparatet ble brukt til barn med ADHD (Æsculap 1958; 38(8): 123). 


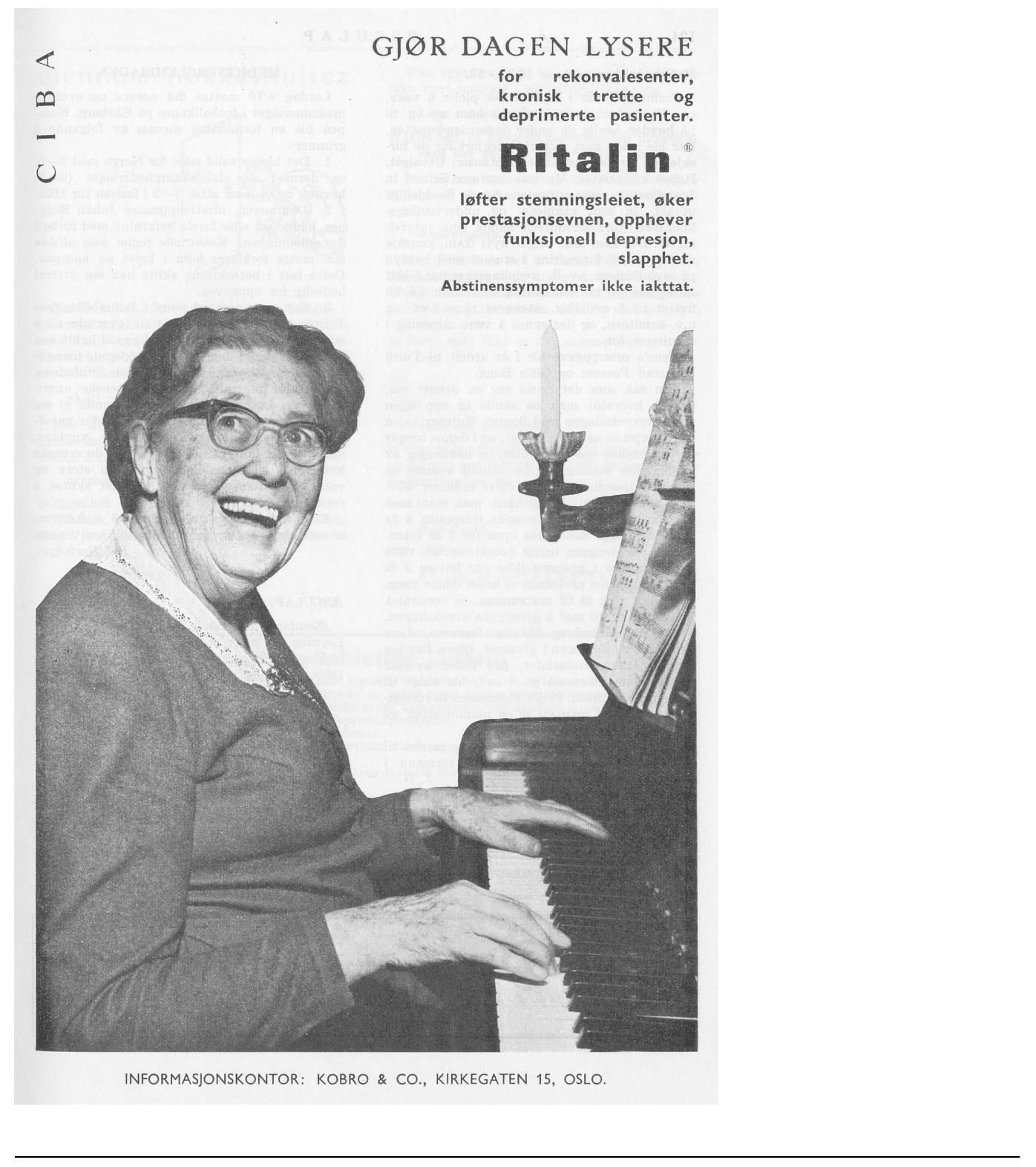

Publisert: 9. november 2020. Tidsskr Nor Legeforen. DOI: 10.4045/tidsskr.20.0782

(C) Tidsskrift for Den norske legeforening 2020. Lastet ned fra tidsskriftet.no 